\title{
Maria Pia fecit / By Maria Pia: the observed AND THE OBSERVER. SOME REFLECTIONS ON GENDER ISSUES CONSIDERING THE CASE OF Queen Maria Pia, The Photographer
}

\author{
Teresa Mendes Flores
}

\begin{abstract}
This article discusses some aspects of the status of women amateur photographers during the turn of the $19^{\text {th }}$ to $20^{\text {th }}$ centuries, considering the case of the Portuguese Queen Maria Pia of Savoy (1847-1911). We acknowledge the difficulties of making the historiography of women photographers in Portugal, due to the scarcity of sources and archives, and the lack of questions about these absences and their reasons. These facts have contributed to a history of photography in Portugal that consists of a succession of male names of "great photographers". Asking questions about "the other half", as well as broadening conceptions of photography to include the diversity of their practices may contribute to highlight the gender constructions raised by photographic practice. It also will help to understand the factors contributing to the limited access of Portuguese women to this practice and the lack of their public visibility, during this period.
\end{abstract}

KeYwORDS

Maria Pia; amateur photographers; gender; visual culture; history of Portuguese photography

\begin{abstract}
RESUMO
Este artigo discute alguns aspetos do estatuto das mulheres fotógrafas amadoras durante a viragem do século XIX para o século XX, a partir do caso da rainha portuguesa Maria Pia de Sabóia (1847-1911). Verificamos as dificuldades de proceder a esta historiografia de mulheres fotógrafas em Portugal, pela escassez de fontes e arquivos, e pela falta de interrogações sobre estas ausências e as suas razões. Estes factos têm contribuído para uma história da fotografia portuguesa que consiste numa sucessão de nomes masculinos de "grandes fotógrafos". Colocar questões sobre "a outra metade", alargar conceções de fotografia e incluir a diversidade das suas práticas poderá contribuir para percebermos as construções de género suscitadas pela prática fotográfica e as razões que dificultaram, neste período, o acesso das mulheres portuguesas a esta prática e à sua visibilidade pública.
\end{abstract}

\section{Palavras-Chave}

Maria Pia; fotógrafas amadoras; género; cultura visual; história da fotografia portuguesa 
But, you may say, we asked you to speak about women and fiction - what has that got to do with a room of one's own? (...) A woman must have money and a room of her own if she is to write fiction. (Virginia Woolf, 1931, p. 5)

Maria Pia de Sabóia (1847-1911)' would not have lacked a room of her own, to devote herself to the arts. Her status as a queen gave her the right to these chambers, described in great detail, in February 1865 , by the architect responsible for the works of redecoration at Ajuda Palace. Also a photographer, Joaquim Possidónio Narciso da Silva (1806-1896) spoke in glowing terms about the good taste of Maria Pia: "let us admire what there is of more charming, rich and of better taste, penetrating in the chambers of her majesty the queen" (Silva, 1865). The architect does not describe, in this text, the painting studio of the queen, on the top floor, or the cabinets and several rooms of storage, adjoining these spaces, where she kept mixed together both the painting and the photographic materi$\mathrm{als}^{2}$. On the other hand, a certain economic independence was the result of her status as a monarch, with an annual income attributed to her own royal house and an administrative manager under her responsibility. In the archives of Ajuda Palace, there are several invoices of the acquisitions of the queen, where the expensive materials for painting and photography are included (cameras, coated glass plates, chemicals, laboratory accessories, etc.). All materials were acquired at the most important commercial houses, both Portuguese and foreign (Andrade, 2011; Garden, 2016). Maria Pia was an amateur painter and photographer, like several members of her family. However, her images have rarely been seen outside of domestic circuits.

Despite satisfying two of the basic conditions (privacy and economic independence) a woman should attend to develop an artistic activity, according to Virginia Woolf -anyone, actually - , Maria Pia was never recognized as a "Queen-artist". Something that, despite various constraints, his son, the King D. Carlos, got ${ }^{3}$. In the field of photography, Maria Pia achieved a certain notoriety by participating at least in one photography exhibition. In this occasion, she obtained a prize (out of competition) and some attention from the press. It was the I National Exhibition of Amateur Photographers that was

\footnotetext{
' Maria Pia of Savoy (1847-1911), fifth daughter of Victor Manuel (1820-1878), king of Sardinia, and of Maria Adelaide of Habsburg Lorraine (1822-1855), archi duchess of Austria, was born in Turin the 16th of October 1847. Married in this city, by power of attorney, with the king D. Luís I of Portugal, on the $27^{\text {th }}$ of September 1862. The young queen, aged 14, arrives in Lisbon on October 5 of that year to the religious marriage in the church of São Domingos, near Rossio. She will live in Portugal during 48 years. She will go back to Italy after the establishment of the Republic, precisely the 5 of October of 1910. She will die in the following year.

${ }^{2}$ Did it not yet exist on that date? Be that as it may the painting studio will be part of the Palace, and it is described by Maria do Rosário Jardim which refers to the material of painting and photography inventoried in the Impounding of Goods, carried out by the republic between 1910 and 1913 (Jardim, 2016, p. 180).

3 The art historians Raquel Henriques da Silva and Maria de Jesus Monge devote a book to the painting of the king D. Carlos (Silva \& Monk, 2007). The authors open the text, precisely documenting how the Portuguese king gained recognition in its own time. They write: "considering that D. Carlos is an important figure of Portuguese naturalism - with equivalent expertise as those personalities of his age, enshrined by Carlos Reis or Veloso Salgado - is not exactly a novelty. In the years 189o, when he participated systematically in the exhibitions of Grémio Artístico, the quality and originality of his paintings have been recognized by all sectors of the critic" (Silva \& Monge, 2007, p. 13). This does not mean that his status as a king was not regarded with strangeness: "about Your Royal Highness D. Carlos, I said last year that he exhibited his watercolours, not as an artist but as a king (...) With the pastels, however, that he now exhibited, the king showed me that with those such transcendent and philosophical considerations, I made myself a fool, I streak!" (quoted in Silva \& Monge, 2007, p. 15).
} 
held in the main hall of the Society of Geography, in Lisbon, between 31 December 1899 and January 22, 1900.

However, it was necessary to wait 116 years since that date, so that her "artistic work", thus assumed and identified, was presented in an exhibition. It was the I National Exhibition of Amateur Photographers that was held in the main hall of the Society of Geography, in Lisbon, between 31 December 1899 and January 22, 1900. As stated by its director, José Alberto Ribeiro, "this is (...) a collection that is virtually unknown, such as the artist whom we now show in an unique facet and at the same time revealing the artistic sensibility of the monarch and of the immense estate left in the Palace of Ajuda at the moment of the establishment of the Republic in 1910" (AA.VV., 2016, p. 9).

In this text, dedicated to the topic of photography and gender, I intend to approach the practice of Maria Pia as a photographer to ask a few questions about the persistent invisibility to which women artists and photographers are devoted to 4 . For this, it will be important to determine the role played by women in photography during the late $19^{\text {th }}$ century to early $2 \mathrm{O}^{\text {th }}$ century. It will be also of great interest to determine which conditions have benefited and which have harmed women's development and visibility as photographers, both in Portugal and in Europe and North America.

It will also be relevant to put in question the scientific paradigms underneath the history of photography that, in Portugal, have enabled such an absence without even noticing it. If we admit that there were not any women photographers, what are the reasons for that? If, on the contrary, they existed, where are they? Who were they?

The feminist movements have pointed out these issues which contributed to the development of a critical perspective in the social sciences. A feminist approach questions the reasons for the absence of female protagonists in social, cultural and even psychological terms (Vicent, 2012).

Feminist approaches, in their diversity (Tavares, 2011), do not advocate the supremacy of women over men (it is still necessary to clarify!). Their aim is to contribute to gender equality within the various fields of action. This goal implied a criticism of the unquestioned notions of subject and object of knowledge. Before feminist criticism, especially before the "second-wave" feminists of the 1960s and 1970s, these were notions practically considered to be instances "without gender"- that is, falling on the norm of "the universal masculinity" (Collin, 2010). By the action of feminist movements, in a critical context marked by Marxism, post-structuralism and psychoanalysis, the various social sciences have had to direct their attention to the phenomenon of the social and historical constitution of gender and subjectivities, and to politicize their own places as scientific knowledges (Nochlin, 1988; Pollock, 1987; Mulvey, 1989). It is in this context that the issues of visuality and visual culture also emerge as constituent elements of subjectivity and gender. Questions such as "who looks?", "who has the right to look?", "who is seen?", "how are the powers of seeing and being seen distributed?", "what can one

${ }_{4}^{4}$ The estate of Maria Pia is not yet catalogued so as to be consulted by the public. I've resorted to images that are accessible in the database MatrizPix and to the catalog of the exhibition referred to. I thank the author Maria do Rosário Jardim for the precious information of her article. She mentions the existence by the time of the republican inventory of about 300 photographs attributed to the queen. 
see and show?" or "what should we hide?" also have a gender. These questions were at the origin of this discipline - or indiscipline, as W. J. T. Mitchell (1995) puts it. They contributed to implement a critical overview of the history of photography and of the optical media (Naomi, 1994; Wells, 2003; Nameghy \& González, 2013).

\section{WHOM DOES NOT SHOW, WILL NOT BE REMEMBERED: THE DIFFICULTIES OF A CRITICAL history OF PORTUGUeSE PHOTOGRAPHY.}

Although women's studies in Portugal have progressed in various fields, their influence is much mitigated in the historiography of photography. The issues of gender, instead of being received as valid, are often a cause of devaluation, denial, and even irritation.

The generalist history of reference in Portuguese historiography of photography is António Sena's History of the Photographic Image in Portugal-1839-1997, published in 1998. In this text the vast majority of the authors referred to are men. The same goes with regard to images published. Throughout the work, 16 women photographers are referred to (in the main text), among hundreds of male authors. Of these women photographers, four are contemporary foreign photographers (Margaret Monk; also film maker Agnes Varda; Sabine Weiss, and Alma Lavenson) and eight are Portuguese: Helena Almeida (n. 1934), Maria Madalena Soares de Azevedo, Auzenda Coelho de Castro, Alice Gentil Martins, Inês Gonçalves (n. 1964), Teresa Siza (n. 1948) and Júlia Ventura (n. 1952). Only Helena Almeida's work is published with three series of images (Painting Inhabited, 1977: Sena, 1998, pp. 312; Drawing Inhabited, 1976: Sena, 1998, pp. 315; La Maison, 1984: Sena, 1998 , p. 318). We can add a 17th name, if one includes the scientific image published on page 353, by the scientist Hanna Damásio (n. 1943).

The names referred concerning photographers of the $19^{\text {th }}$ and early $20^{\text {th }}$ centuries, include only four women: Madame Fritz, Margarida Relvas (1867-1930), Maria Pia (18471911), and Maria da Conceição Lemos de Magalhães (1863-1949). Three images by this author were published, probably from António Sena's own collection, who seems to appreciate them, particularly. All three photographs were from 1908 (Urban Village: Sena, 1998, p.194; Effects of Cloud: Sena, 1998, p. 207, and In the Threshing-floor: Sena, 1998, p. 217) ${ }^{5}$. Given the temporal frame, the recent book Treasures of Portuguese Photography of the $19^{\text {th }}$ Century, by Emília Tavares and Margarida Medeiros (2015), only mention and publish photographs by Maria Pia and Margarida Relvas. Gender issues were not raised about this striking unbalance. Even if it were to acknowledge that there were not women photographers.

In fact, to António Sena and according to his vast archive-collection of Portuguese photography, the practice of photography did not proliferate among Portuguese women, up to the 2nd World War, since:

\footnotetext{
${ }^{5}$ In 294 illustrations published in this book, only seven images have women authors. A percentage of 2.3\%. Many people argue, probably with good reason, that gender should not be a criterion for the selection of meaningful images to any history. However, it is striking to notice that choices with "no gender criterion" often choose a majority of male authors as something "natural". This unbalance deserves to be debated.
} 
Maria da Conceição Lemos de Magalhães is a rare case, until 1940, of a woman linked to photography in Portugal, [in addition to Madame Fritz, 90 years before]. Let us explain that her activity has developed since 1905 until about 1915, and it was not limited to the simple push of the button of the machine. On the contrary, she was interested by its treatment in the laboratory and she dedicated herself to the study of the chemistry of photography. Her proximity to the pictorial work of her contemporary, Aurélia de Sousa (1866-1922), is not unlikely (...). The images contaminate each other. (Sena, 1998, p. 217)

It is understood, by the excerpt, that the author was sensitive to the issue of women photographers, since he raises the issue and recognizes that virtually they did not exist and were "a rare case". However, it is curious that the author felt the need to add an explanation: it goes more or less in the sense of evidencing that we are faced with a woman who is a "true photographer", since she "did not limit herself to the simple push of a button". We can conclude that the need for this clarification is only justified in the face of the common (?) expectation that Portuguese women would be limited to the "pushing" of buttons. In the plenty of cases of male authors appearing in this book, this addition is not considered necessary. It is evident that the comment of António Sena intends to praise the work of this photographer. On the whole, he seems to suggest, then, that women would only have a home practice.

And if, as he stated, things have changed in Portugal after the Second World War, how can one justify the persistent rarity of female photographers referred to in his book as significant since then?

António Sena undertook an extraordinary work of fixing of documentary sources. However, he focused on the public dimension of photography. He does not mention the private use of photographic albums and private images, family snapshots and other dimensions of photographic popular culture. A modernist conception of photography and of the photographer as an artists is prevalent, benefiting a discourse on the essential and distinctive features of the media. As Rosenblum (1994) puts it, playing with the English word, this book also conforms to the idea that we are facing an "His"- "story": a story of him or them .

History must be documented. In the case of this book, the documents used were fundamentally related to the practices of public display, whether in exhibitions or in the magazines. It ends up speaking mostly of the names that were also spoken in each historical period. Whom did not show, was not remembered! Furthermore, the market of ancient photography also values the most well known names, which are those who were most talked about and commented upon. The most well established authorships and the most recognized ones (by historiography) also constituted, until recently, the main criterion of formation of the public archives of photography, contributing to the perpetuation of their male façade.

Thus, considering new sources and concepts of photography, including private family archives, poor and formatted pictures, including those produced for the masses, 
etc., as a result of an increasing popular culture, will probably help to uncover more women photographers. In addition, it is worth to look at the old sources with new eyes and new questions ${ }^{6}$.

Even admitting that Sena is right to consider that women photographers were rare or non-existent, given the masculinity of the archives, it is always necessary to question the policies of visuality that structured these practices of vision and the discursive formations of the archives, as active phenomena in the social construction of gender, of ethnic and class identities to each and every one. On these social processes must histories be attentive.

\section{Made by Maria Pia}

Maria Pia is one of the few authors mentioned in the History of the Photographic Image in Portugal (op. cit.), and this happens due to her participation in the I National Exhibition of Amateur Photographers, in 1899, already referred to. On this date it is likely that she already devoted herself to photography at least for a decade. According to Maria do Rosário Jardim, the first signed prints that are now in the collection of the Ajuda Palace, date from 1892 (Jardim, 2016, p. 170) (Figure 1). In addition, the notebooks of the servants of Queen Maria Pia document her regular photographic activity soon after 1889, the year of the death of D. Luís. Her status changes at this time and so does her availability, that increases.

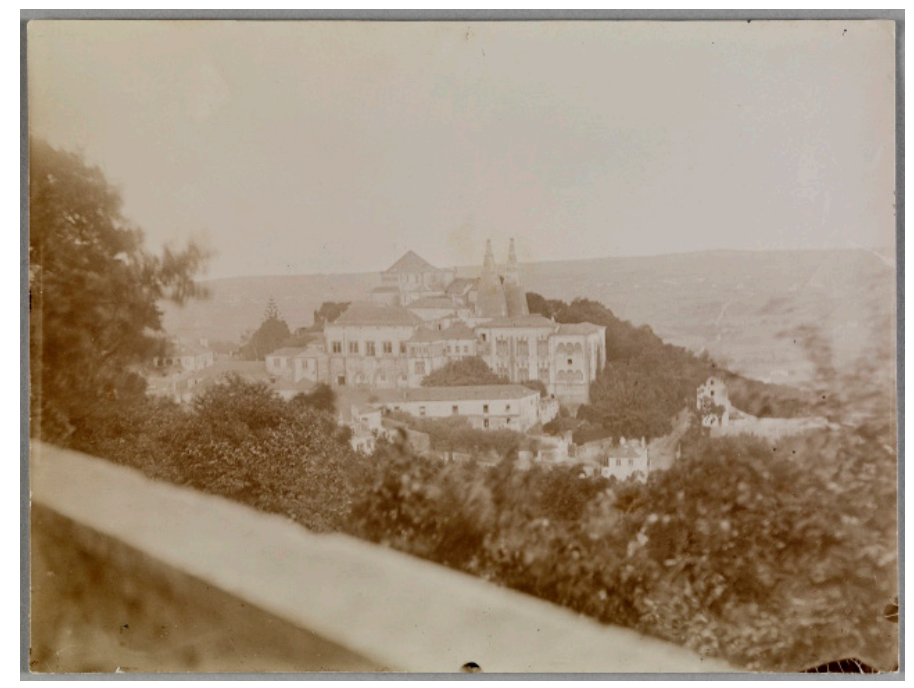

Figure 1: Sintra, Palácio da Vila, Maria Pia, 1892. Gelatin and Silver Print on paper, 20,9x15,7 cm. Inv. PNA 62334

Source: The Ajuda National Palace, DGPC/ADF. Photographic Reproduction by Luísa Oliveira

Time is an important factor for any artistic creation and to photography in particular. Photography is always associated with more or less long tours and to a certain flânerie, a form of wandering fast gaze that was in fashion at the time.

\footnotetext{
${ }^{6}$ A recent exhibition was held showing the photographic albums of Portuguese Queen D. Amelia (AA.VV., 2015).
} 
Her education was, of course, highly taken care of and is profusely documented (Vaz, 2016). It's not the same as to her learning of photography. But, as well as she had private tutors for drawing and painting, a frequent situation among men and women of her class, the same might have happened to the learning of photography. It is known that D. Luís had a professor of photography?.

It also seems clear that this learning of photography arises in the context of her activity as a plastic amateur artist. This category of amateur was in part due to the fact that learning was done at home by private tutors. But it also was in tune with the universe that was assigned to women: the private sphere. Sandra Leandro writes about the women artists of the early $20^{\text {th }}$ century and refers to the role that the arts played in the education of the rich women, as a form of status: "it was the practice of feminine gift very suitable to ladies with possessions, it was a way to figure and make figure, adding presence and perhaps personality - a mode of women's presentation to society" (Leandro, 2011, p. 272).

Even though this was the social meaning, somewhat limited, which led women to training opportunities, the truth is that many of them, as Maria Pia, took this opportunity to develop with the arts a genuine and serious relationship (Figures 2 and 3). Even though never becoming professional artists. However, in both the traditional arts and the photographic art the status of amateur was very well praised and had its own circuits of exhibition and display.

"Maria Pia ...fecit", or simply "MP F" is the signature that is inscribed in pencil on the back of many of the photographic prints of Maria Pia preserved in her estate at Palácio da Ajuda. This care with the signatures highlights the appreciation given to photography and expresses the importance that she assigns to it as an independent art. It also allows us to consider that Maria Pia did not profess, most probably, the famous position of the French poet Baudelaire, for whom photography should be merely a technical helper, "handmaid of the arts and sciences" (Baudelaire, 1987).

In several cases, Maria Pia adds the date and the location, identifies the initials of the people photographed, indicates the number of copies and what to do with them. She writes down processing information for the image and their specific conditions. According to Maria do Rosário Jardim these notes show that "Maria Pia participated in and managed with care all stages of the process of photography" (Jardim, 2016, pp. 170-171). It is also known at least one photographic laboratory, at the Chalet Royal, in Estoril.

7 Diário de Notícias, July 1874: "the royal family is in Queluz, where the Queen is dedicated to sculpture [...] and D. Luís is dedicated to photography under the direction of the photographer Oliveira" (quoted in Jardim, 2016, p. 170). 


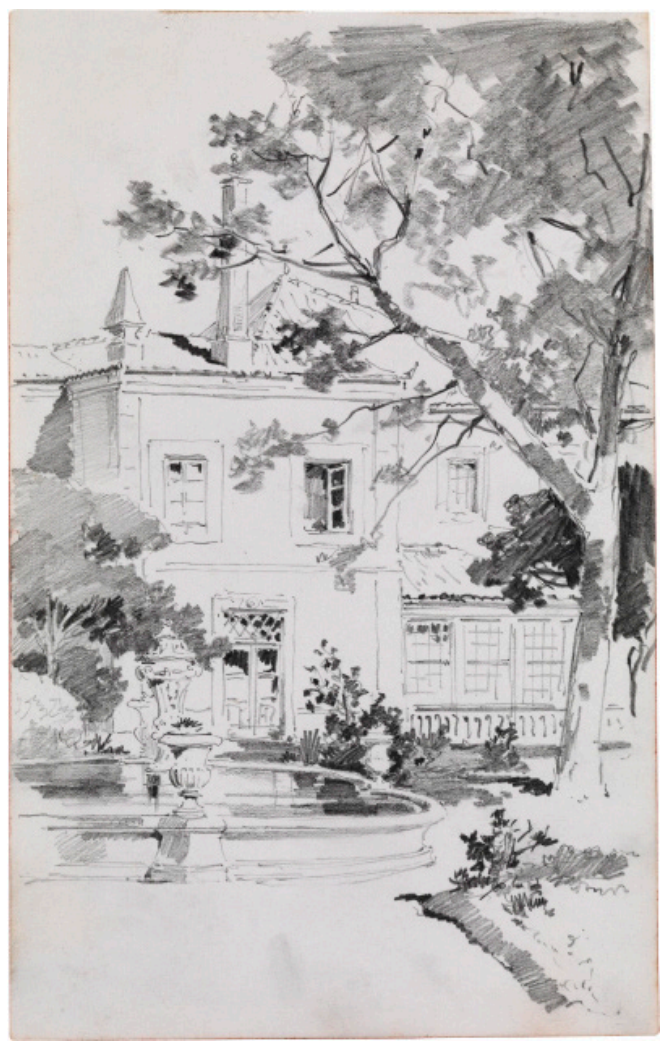

Figure 2: The Palace with a water tank, Maria Pia, 1887-1889. Gelatin and Silver Print on paper, $14 \times$ $22,7 \mathrm{~cm}$. Inv. PNA $58279 / 19$

Source: The Ajuda National Palace, DGPC/ADF. Photographic reproduction by José Paulo Ruas

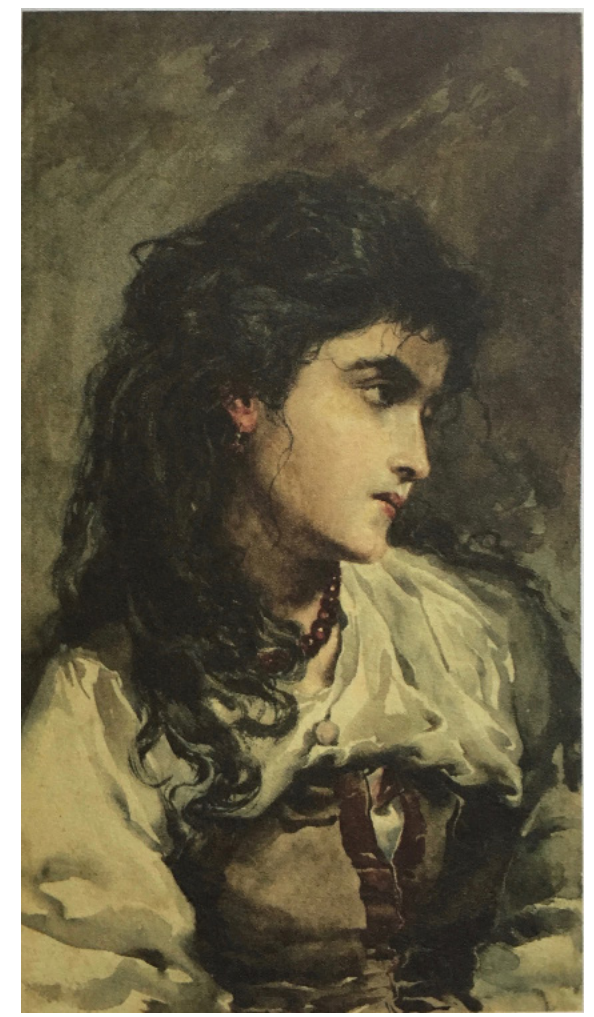

Figure 3: Gipsy, Maria Pia, undated. Watercolour on paper, 45,6x25,3 cm. Inv. PNA 4656 Source: The Ajuda National Palace, DGPC/ADF. Photographic Reproduction by Maria Teresa Flores 


\section{Maria Pia...In The LAB?}

There is no doubt that the King D. Carlos used this laboratory. However, some questions have been raised about whether Maria Pia has used it or not. Maybe due to her status as queen, Maria do Carmo Rebello de Andrade wrote on the photo biography of Maria Pia, that: "we can't imagine Lady Maria Pia in these laboratory work. Certainly only D. Carlos made developments" (Andrade, 2011, p. 165). But, why "can't we imagine?". The knowledge and the opportunity did not lack to Maria Pia. This knowledge is assumed taking into account the literature on photography that the queen usually bought ${ }^{8}$. The opportunity is linked to the social context of the time. It was widespread among the amateur photographers, including the aristocrats, the dedication to all phases of the process.

It is true that, at this period, we have already assisted to a strong industrialization of many procedures of photographic practice. This was an important factor leading to the huge expansion of the sector, including in Portugal9. To buy previously sensitised plates to do the exposures and papers to the printings has become standard practice, and a very advantageous one. However, among those who developed artistic ambitions, or simply demanded higher quality of their images, the common desire was to control development and printing of those images.

These seems to have not been different for amateur photographers. At least among English and American women developing and printing were common practices. We can tell it bearing in mind the debate opened up by the newspapers, such as Photographic News, Eye and American Amateur Photographer, in December 1889, about the convenience to admit or not women in the photo clubs.

The vast majority of these clubs accepted women as members, but some refused them on the grounds, among other objections, that it would be a prejudice to the reputation of ladies to share the laboratory with men who were not their husbands. Moreover, that it would oblige the male members to change their behaviours, seeing themselves obliged not to drink, smoke nor using inappropriate language.

Catherine Weed Barnes (1851-1913), a member of the Society of Amateur Photographers of New York, and an activist of the rights of women photographers, responds to this by defending equality:

does that gentleman consider a photographic club a place which cannot be frequented by ladies without loss of self-respect or the respect of others? Does such a reflection bear more heavily on one sex than on the other? The gentleman does not say that ladies do not do good work, but he wishes to

\footnotetext{
${ }^{8}$ Maria do Rosário Jardim refers to in her article, "the access to journals and reference manuals, including (...) the wellknown General Treaty of Photography Theoretical and Practical, 1891, by Arnaldo Fonseca, or foreign authors like Alphonso Davanne, La Photographie: traité théorique et pratique, 1886-1888, P. Fabre-Domergue, Guide du Photographe et de I amateur photographe, 1888" (Jardim, 2016, p.170)

${ }^{9}$ In the first issue of the fourth year of publication of the journal Echo Photographico, Soares d'Andrade, its director, thanks to the journal's subscribers for their fidelity. He comments that there were about 3 thousands subscribers: "which among the three thousands subscribers that have followed us up to today, will not accompany us in this beautiful crusade which with so much punctuality we have achieved, thanks to this wonderful protection, very unusual in our uncultivated country ( ... )?" (Editorial, 1909, p. 2)
} 
refuse them the advantages he confesses as necessary for his own sex. They may work, but must do it by the hardest way, and lose the mental attrition possessed by their brothers. This work in no sense derogates from womanly dignity, and the laborer is just as worthy of her as his hire. (Barnes, 1889, p. 224)

From her own experience, it is clear that it was common for women to enter the laboratory. Being able to use the lab of the clubs was one of the advantages of becoming a member. Barnes writes:

in my own experience I have found that those gentlemen who happened to be in the dark-room at the same time as myself seemed to feel it no trouble to lay aside their cigars and remove their hats while I remained in the room. In other words, they did not find it difficult to act like gentlemen. (Barnes, 1889, p. 223)

And she adds:

photography is a peculiarly suitable work for ladies (...) Let them get needful information and practical help wherever they can, and there are societies which are willing to give it. I say, therefore, to all societies, to give us a fair field and no favor; let us win our spurs side by side with our brothers, and the result thus gained will be worth all the trouble required. The day is coming, and will soon be here, when only one question will be asked as to any photographic work - "Is it well done?". (Barnes, 1889, p. 224)

The participation of women in all phases of the photographic process is also mentioned in a news story from the New York Times, in June 1890:

the large number of girls who have caught the photographic craze this Spring is noticeable. Girls leveling tripod cameras or pressing the button on detective and hand cameras are a frequent sight in the Park and out in the subsurbs of the city. Many of them are going into the subject of photography with a commendable zeal, and are not content with simply working the camera, but are developing the plates and even making various developing solutions. (Photographers at Work, Young Women Becoming Enthusiastic Over the Art, 1890, p. 8)

In another article with the suggestive title "Women Who Press the Button", the same journal indicated the reasons for this zeal: "the most successful women do all the work - developing, printing, etc. - themselves, because different plates require different treatment, according to the length of time they have been exposed - which is, of course, best known to the one who takes the picture" (Women Who Press the Button, 1893, p. 18).

By contrast, the Portuguese newspaper Echo Photographico (1906-1913), in an article entitled "Woman and photography" (A mulher e a fotografia, 1909, pp. 18-19), protests 
against the delay of the country, because it is not common to see in Portugal, women with cameras in tow. Interestingly, the news also refers to the inappropriate language of men towards an English woman photographer that was passing in the streets of Lisbon:

in this land, unfortunately, when you see someone with a photographic camera, there is no gawk that does not look, nor stupid who does not play his saying: "will you take my picture ?". When we see this "miss" we are immediately reminded that for a Portuguese lady the possession of such a camera would be something extraordinary and never seen! (A mulher e a fotografia, 1909, pp. 18-19)

However, being the Portuguese royal family moulded by foreign influences, and being it so common among foreigner women to participate in all phases of the photographic process, it would not seem strange that Maria Pia would also follow the example and work her images in the laboratory, by herself. Even if she is an aristocrat. This social condition gave her, moreover, the privilege of having her own lab and not be, therefore, subject to any such constraints.

\section{AN ACTIVITY "PECULIARLY SUITED TO WOMEN"}

Although a technological activity, photography was from the beginning seen as appropriate to women. Maybe because it was considered comparatively easier than the other arts, or because it was perceived as being closest to the applied arts and crafts, as a branch of the graphic arts, photography was seen as appropriate to women. Furthermore, because it was seen as something related to contemplative activities, such as walking in nature "to contemplate the views" which were part of upper class education. These walks "through nature" shaped the education of aristocrats, both men and women, since the $18^{\text {th }}$ century (Hunt, 2002). It was common to bring along to these walks such devices as cameras obscure and Claude Glasses, that allowed the transformation of any place into a more vivid and spectacular image. From 1804 onward, the year of its invention, the use of cameras lucidas of Wollaston (1766-1828) became common, in order to assist in the drawings. So, drawing was encouraged to record observations and as a way to educate aesthetic taste, which took Nature as the only virtous model. All these technical devices were helpful to improve observation and increase knowledge of nature, with both scientific and aesthetic implications (Mendes Flores, 2016). It is in the wake of this tradition that photography was invented. In the same New York Times article of 1890, quoted above, the same idea was highlighted:

habits of observation are often implanted in the mind by picture taking that would never have been gained but from its practice. The work is clean and healthful. The outdoor tramps in search of the beautiful and the artistic in nature are invigorating and strength-building, while the development of plates requires care and close attention. (Photographers at Work, Young Women Becoming Enthusiastic Over the Art, 189o, p. 8) 
Recent works (mainly foreign) have underlined the important role of women since the beginning of photography. Examples are Constance Fox Talbot (1811-1880), the wife of the English inventor, and a large group of women of that family; Genevieve-Elizabeth Disdéri (1817-1878), the wife of the famous inventor of the Carte-de-visit, or the botany Anne Atkins (1799-1871). In addition to the pioneers, from early on, several women were established in their own name or, more often, in partnership with their husbands, as professional photographers. Widows who have taken over photographic studios, and were themselves photographers; large groups of women which exercised as laboratory workers, performing the different repetitive tasks within professional studios, etc, are many other dimensions of this relationship of women with photography.

In Portugal, we should refer to the research of Cátia Salvado Fonseca (2016), about the role of Relvas family, highlighting the role of Margarida Relvas. In the area of professionals, Maria E. R. Campos, advertised herself, since 1888 , as the first women photographer, with a studio on the Calçada do Duque, $n^{\circ} 18$, Lisbon.

Margaret Denny has investigated these cases in the United Kingdom and the USA. Denny concludes that, at least in the Anglo-Saxon context, "although women were not in equal footing with their male counterparts, women photographers resisted gender expectations and went beyond assumed separated spheres" (Denny, 2009, p. 802).

The support that Queen Victoria gave to photography is generally considered influential for the adoption of the new image on the part of the aristocracy and the high bourgeoisie (Smith, 2015). The Portuguese royal family is one of those cases.

This is then, a taste that spread among the European elites. It manifested in the frequency of professional studios in order to have their portraits made. But the interest was also evident in the high numbers of the elite members that took photography as practitioners. Monarchies took political advantages of this activity, which they helped to nobilitate.

However, it is in pursuit of the landscape tradition, of knowledge and enjoyment of Nature, that we can understand the creative activity of Maria Pia. Estoril, Sintra and Cascais, are her preferred locations (Figures 4 and 5). The majority of her photographs represent this region, resulting from long tours, sometimes daily: "Your Royal Highness was in the garden with Queen Margaret, taking pictures" (Jardim, 2016, p.171); "after lunch Your Royal Highness was taking photographies"; or, "Your Royal Highness did not walk in bikes, she went out of Peninha at 7 o'clock, was taking photographies and came to Estoril at 9 hours p.m." (Jardim, 2016, p. 174). 


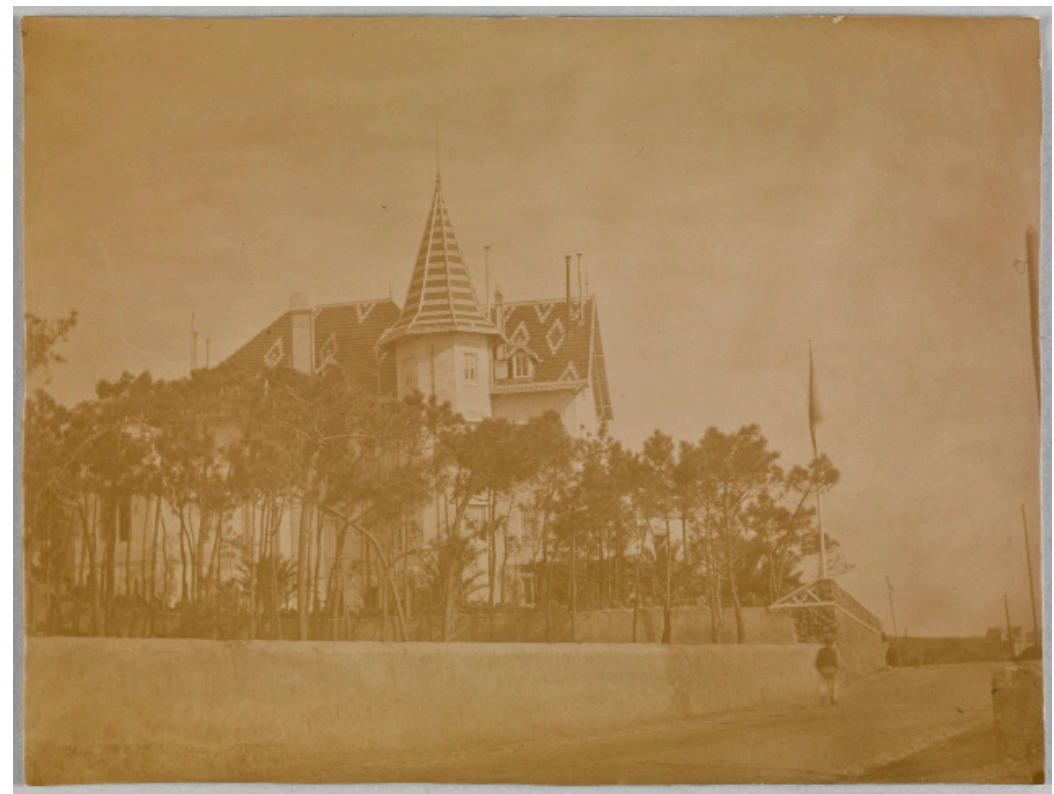

Figure 4: The Royal Palace of Estoril, Maria Pia, 1894. Gelatin and Silver Print on paper, 15,8×21 cm. Inv. PNA. 62263 Source: The Ajuda National Palace, DGPC/ADF. Photographic reproduction by Luísa Oliveira

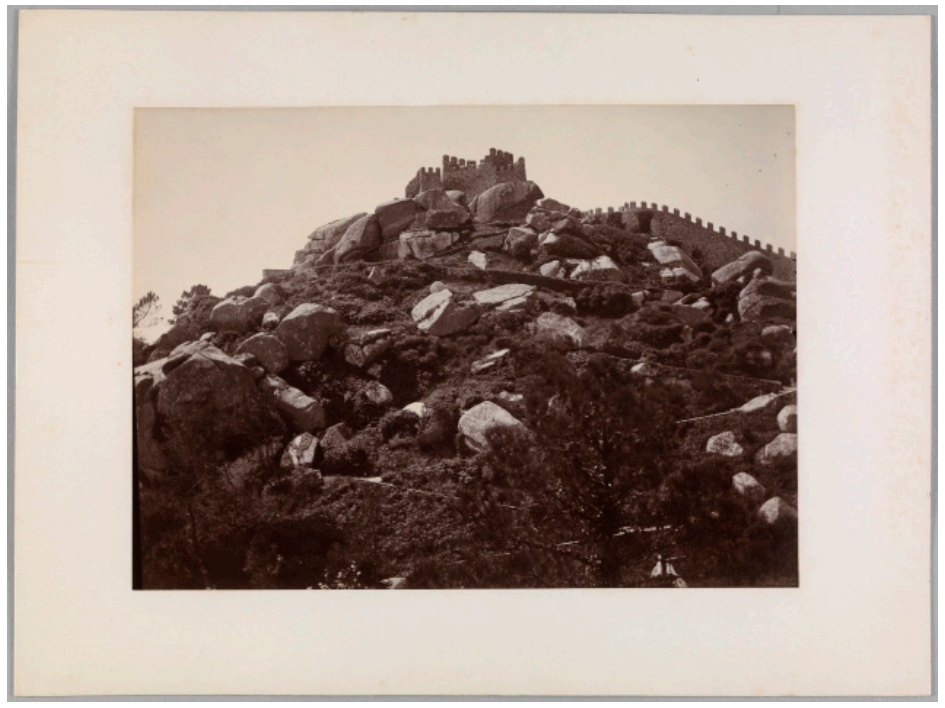

Figure 5: Sintra, The Moorish Castle, Maria Pia, 1893. Gelatin and Silver Print on paper, mounted on a cardboard. Image: $15 \times 20,6 \mathrm{~cm}$; Cardboard: 21,3 $\times 28,4 \mathrm{~cm}$. Inv. PNA 62600

Source: The Ajuda National Palace, DGPC/ADF. Photographic Reproduction by Luísa Oliveira

The adoption of the bicycle is one more element that reveals her modern attitude, that is, the taste for technical innovations, that she quickly adopts (Figure 6). Which also reflects her cosmopolitanism (Pallier, 2006; Peacock \& Cerqueira, 2007; Lopes, 2011).

The association between photography and bicycling is another of the hallmarks of visual culture at the end of the $19^{\text {th }}$ century. Both activities are considered "sports" and were both highly recommended for the ladies, whose time was to be occupied in uplifting activities for the soul (the careful observation, basis of all true knowledge) and the body (the physical exercise of biking or walking). And that would not be very difficult (a frequent argument). The popularity of the bicycle "to the ladies" appears in the 1880's, 
precisely with a type of bike, virtually identical to the contemporary models, the so-called "safety bicycle", since it eliminated the disadvantages of the models of high wheels that easily fell.

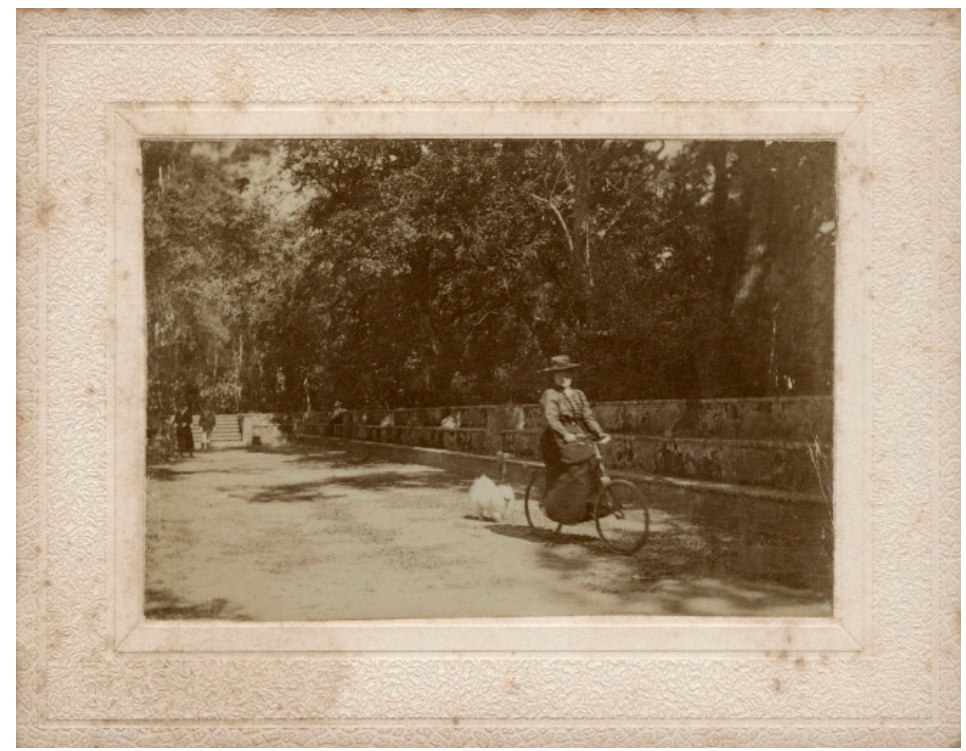

Figure 6: Maria Pia riding her bike in the Palace of Queluz. Unknown Author. Gelatin and Silver Print on paper, mounted on a cardboard. Image: $15 \times 20,6 \mathrm{~cm}$; Cardboard: $21,3 \times 28,4 \mathrm{~cm}$. Inv. PNA 62600 Source: The Ajuda National Palace, DGPC/ADF. Photographic Reproduction by Luísa Oliveira

The relationship between the two activities was promoted by special clubs: the Photo-Vélôs. The Photo-Veló-Club of Oporto published, in 1899, a Bulletin directed by Domingos Alvão (1872-1946). He also directed the Pratical School of Photography of the Photo-Velo-Club - (whose headquarters were located at no. 120 of the Santa Catarina Street).

The newspaper Echo Photographico, had the sub-title "monthly Journal of photographic sport " and during the first years of publication had on its cover a young woman carrying a stereo camera, walking through a natural landscape in more practical clothes (Figure 7).

Despite this explicit appeal to women, that the cover of the newspaper seems to invite, between 1906 and 1910 (the years examined), we found only a mention of 3 women photographers. In the section "Gallery of Contemporary Amateurs", an amateur photographer was presented each month ${ }^{\circ}$. The profile of two women photographers were published: Lady Maria C. Godinho and Nathalia Terra (Galeria de Amadores Contemporâneos: D. Maria C. Godinho, 1907, p. 19; Galeria de Amadores Contemporâneos: Nathalia Terra, 1908, p. 89, respectively). The third women photographer to appear in the pages of the Echo Photographico, was the author of an image published in the section dedicated to the dissemination of members' works. The image is identified with the title "I am Tareco" by Lady Julia Gouveia Gonçalves, from Lisbon (Eu sou o tareco!, 1907, p. 76).

${ }^{10}$ The section begins in issue 5, in October 1906, and lasts over 27 editions. It ends in issue 33, in February 1909. Among the 27 photographers presented, two were women $(7,4 \%)$. 


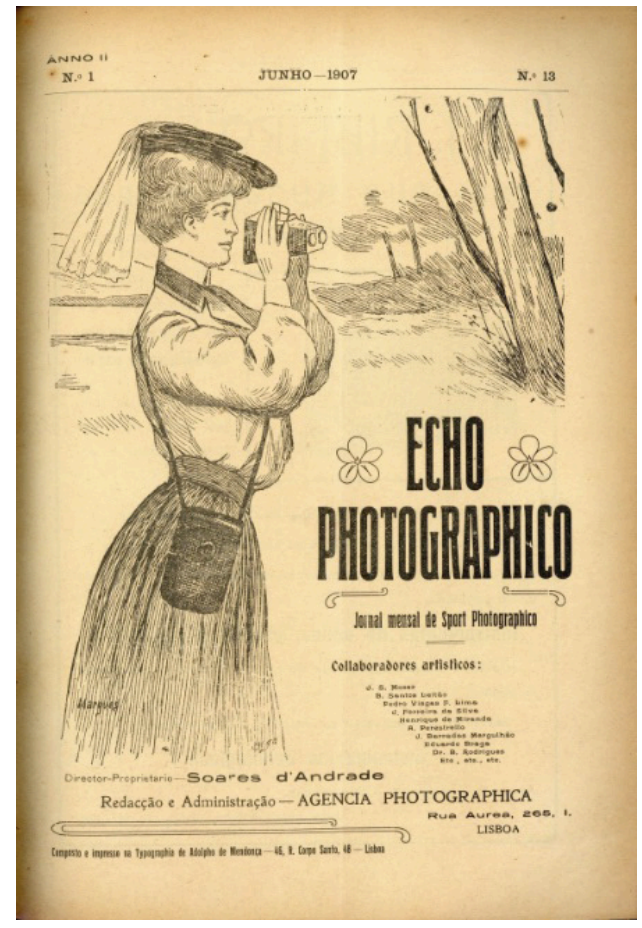

Figure 7: Cover of Echo Photographico. Illustration by Marques Source: Echo Photographico, Jornal mensal de Sport Photographico, 1907, cover; Hemeroteca Municipal de Lisboa

The two authors referred to as "Ladies" were certainly members of the aristocracy. The father of Lady Maria C. Godinho is referred to as being also an amateur. Having a father who is an artist and photographer configures a typical case of women's access to the arts. Nathalia Terra, from the Azores, is presented as a plastic artist. The case of the many visual artists that Sandra Leandro (2011) presents (about 36, during the few years of the 1st Republic), the majority was considered amateur. These artists constitute a group among which we may discover new women in photography, since it is likely that some of these painters were also using photography. That was preciselly the case, recently studied, of the artist Aurélia de Sousa, from Oporto (Vicente, 2016). Alice Rey Colaço, a disciple of the naturalist Carlos Reis, is the author of some of the photographs known of his sister, the actress Amélia Rey Colaço (Barros, 2009). In turn, Virginia de Castro e Almeida wrote and produced films, founding the production company Fortuna Films. A versatile artist herself, would she have also experimented photography? (Leandro, 2011, p. 313).

An example of how photography was perceived during this period, arises from a news of 1905, in Boletim Photographico. Citing a news story published in Diário de Notícias, the Boletim informed that Queen Alexandra of England, in a recent visit to Portugal, was a "sport woman" of photography, whose images have contributed to avoid the fall of a bridge!"

\footnotetext{
"The news, transcribed from Diário de Notícias, is the following: "with a complete education as a "Sport woman" Princess Alexandra is an amateur photographer. And their photos have prevented a tremendous catastrophe: The Princess Alexandra having taken a snapshot of a bridge in the district of Sandringham, noted in the prrinting that there was a tilt on the arc of the bridge. Although her camera was a very expensive device of precision she attributed it to the camera; repeating the snapshot she found the same slope. The Prince of Wales then sent a message to the Company and the engineers did an
} 
To Maria Pia, as well as for many of the artists referred to by Leandro (2011), the visual arts would go beyond a mere recreation. But it was as an "useful occupation" that these activities were encouraged not only among women, but especially among them. Particularly, if they were aristocrats. They were those who had more economic means for such practices.

The photographs of Maria Pia which are accessible to the public, do not follow under the category of family and domestic photography, even if there are a few documenting the leisure activities of the group surrounding the queen. Maria Pia clearly privileged the landscape genre, representing both the fields and the seafronts. The representation of the sea was a famous genre known as "marines", which was very appreciated in the painting of the time. The attention she gave to the monuments, to room interiors, and decorative details characteristic of the architecture, reveal her well educated look and taste (Figure 8). This taste is also evident with regard to the documentation of the people of the region. These representations were very much in tune with the taste of the painters of the time. These search for human "types", turning peoples into the "others," and into the "regional types", emerge in accordance to the works of ethnography and anthropology, as well as the historiography of the time. These sciences were concerned with characterizing the natural landscapes and the cultural regions and countries, contributing to the affirmation of a nationalism trend that was, of course, dear to the monarchy.

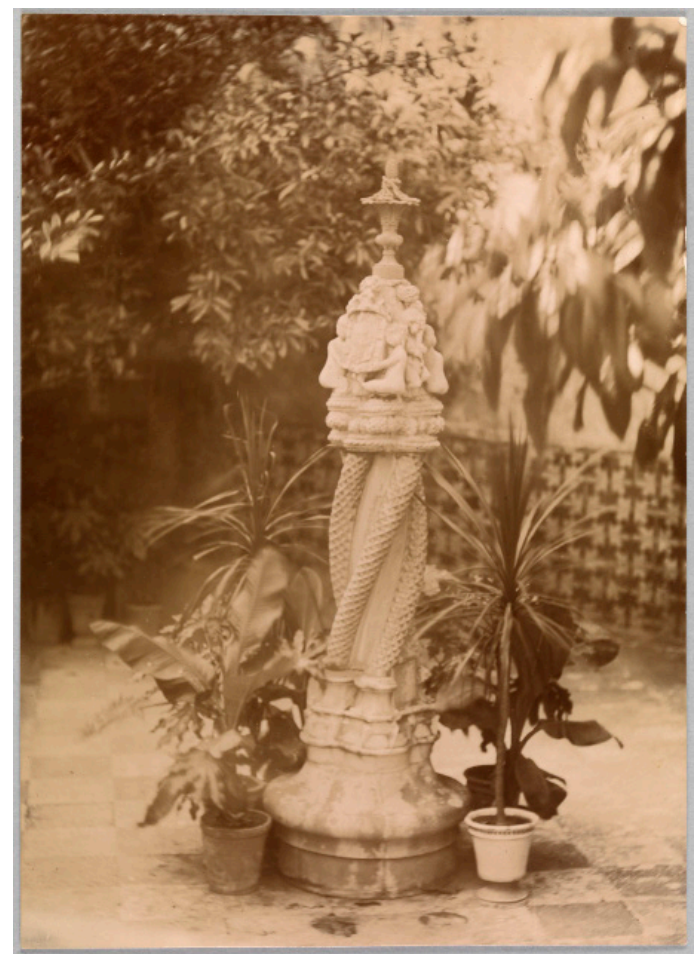

Figure 8: Sintra, Palácio da Vila, Column Torsa in the Courtyard of the Nozzle (or Central plaza). Maria Pia, 1892. Gelatin and Silver Print on paper, $18,1 \times 12,9 \mathrm{~cm}$. Inv. PNA. 61764 Source: The Ajuda National Palace, DGPC/ADF. Photographic Reproduction by Luísa Oliveira

immediate survey and certified that the bridge threatened to ruin. Without the proper warning of the Princess Alexandra, the movements of the locomotive would certainly make it go down in the earth," (A rainha de Inglaterra, amadora de photographia, 1905, p. 50). 
At least in the sample of images accessible to the public, we have not identified a particular interest in the representation of urban spaces, nor an approach characterised by subjective or symbolist values. Maria Pia's most significant aesthetic influence seems to be the naturalist movement. Although the recent movement of Pictorialism may be considered a development of naturalism, it is distinguished from it due to the search for less documentary images benefiting a more openly interpretative view of the subjects. These subjective values were obtained through the use of pictorial effects that resulted in unique images, such as the use of the intentional blur, the scraping of the negatives, the prints experimenting with various pigmentations, the use of gum bichromated prints, platinotypes, etc.. Which were all procedures that do not enter into the vocabulary of Maria Pia. In fact, this is congruent with what was happening in terms of aesthetics in the country.

\section{THE EXHIBITION OF 1899}

The critique of an aesthetic considered too traditional and little in tune with the latest international developments, was put forward by Arnaldo Fonseca in his article about the "I National Exhibition of Amateur Photographers", already referred to. This critical article was published in the Boletim Photographico.

This was one of the (only?) exhibits that Maria Pia has participated in. Maria Pia probably submitted 27 photos to this exhibition (Jardim, 2016, p. 180).

The criticism of Arnaldo Fonseca allows us to realize that the work of Maria Pia is inserted into the current practice in Portugal. It also makes evident what was expected from the amateur photographers, both men and women (these later, never mentioned): they were assigned with the role of avant-garde that, according to Arnaldo Fonseca, was not being fulfilled:

in all the exhibition what was used in a general way for printing the phototypes, were the common processes of gelatin-chloride and gelatin bromide. In platinum papers a very few dared to print. In bichromate I suppose that none. (...) Platinum papers developed in glycerine, and papers coated with arabic bichromated gum, offer a development, a depouillement with the brush, where certain values can be diminished and others stressed; (...) It can clearly give splendid results in modifying the stiffness and fatality attributed to photography. (...) Anyone also, with a single exception, explored purposely with the flou. On the contrary, the majority worried about sharpness, crushing sometimes the greater part of the work. (A exposição nacional de photographia, 1900, p. 27)

"Landscapes and Marines" (Figure 9), as well as "Architecture and Monuments" are the top themes of the list of genres, highlighting their importance in the amateur practice ${ }^{12}$.

\footnotetext{
${ }^{12}$ These statements confirm the news of O Século: "Landscapes and Marines are the dominant genres of the exhibition; and it is regrettable that in the vast majority of the first, there is a lack of the animation of the human figure" (quoted in A rainha de Inglaterra, amadora de photographia, 1905, p. 50)
} 
Interior photography, a sub-theme of "Architecture ", is also popular. Portraits, genre scenes and orientalist works were also present in this edition. The Boletim Photographico publishes one of the photos of Maria Pia, with a very recurrent subject of her images: the trees (Figure 10). But, she deserved little more than a protocol note by Arnaldo Fonseca: "Her M. the Queen Lady Maria Pia and his highness Prince Infant, expose four frames with some bright printings, especially in regard to the choice of subject; between them we highlight the Guincho Beach, where a wave grows under an atmosphere of beautiful clouds" (A exposição nacional de photographia, 1900, p. 20).

In contrast, the critic of the journal Novidades is very enthusiastic: "Her Majesty the queen Lady Maria Pia has superb photographies, representing the launching of a bridge in Tancos, several stretches of the palace of Cintra, and the beach of Cascais" (A Exposição Nacional de Photographias, 1899, s.p.). And broadly speaking about the work of the royal family, this critic states that they present "magnificent photographies by the sharpness, the distribution of light and by the choice of subject". The newspaper $O$ Século argues that photography is an art, and includes Maria Pia in the group of artists: "Who will deny that such a wave of the queen's lady D. Maria Pia (...) are not products of the spirit and exquisite taste, of a temperament of an artist?" (Exposição nacional de photographia, 1900, p. 1).

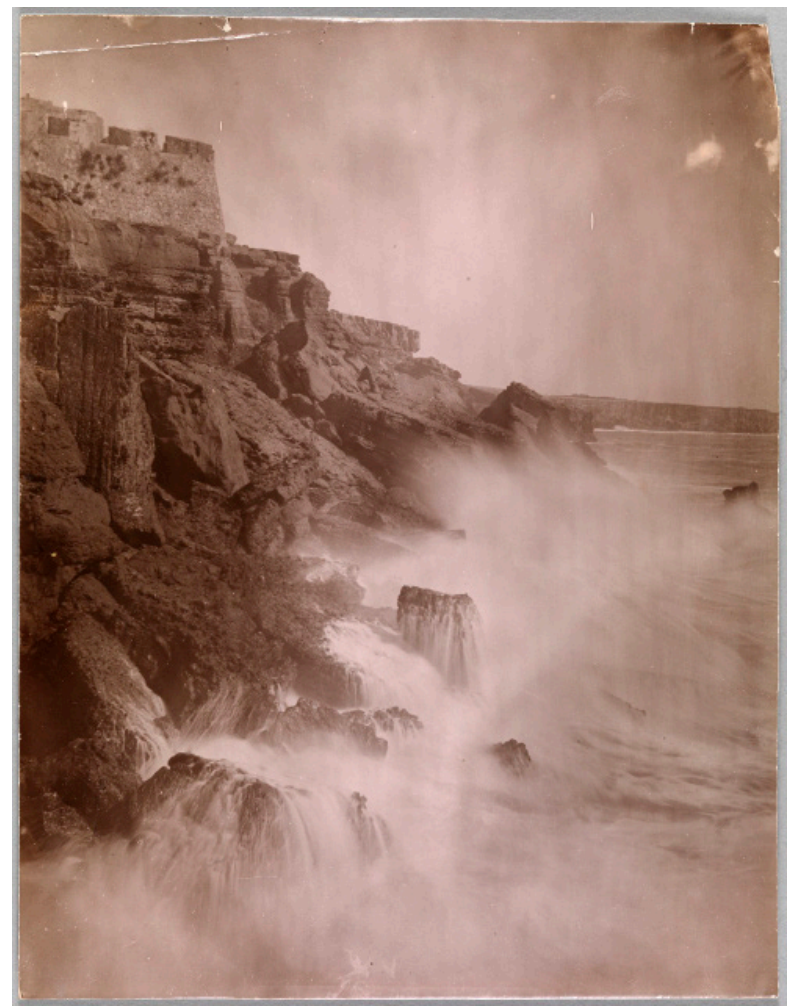

Figure 9: Cascais, Cliffs and Fortification of Guia, Maria Pia, 1894. Gelatin and Silver Print on paper, 20,7 x 15,7 cm. Inv. PNA. 62195

Source: The Ajuda National Palace, DGPC/ADF. Photographic Reproduction by Luísa Oliveira 


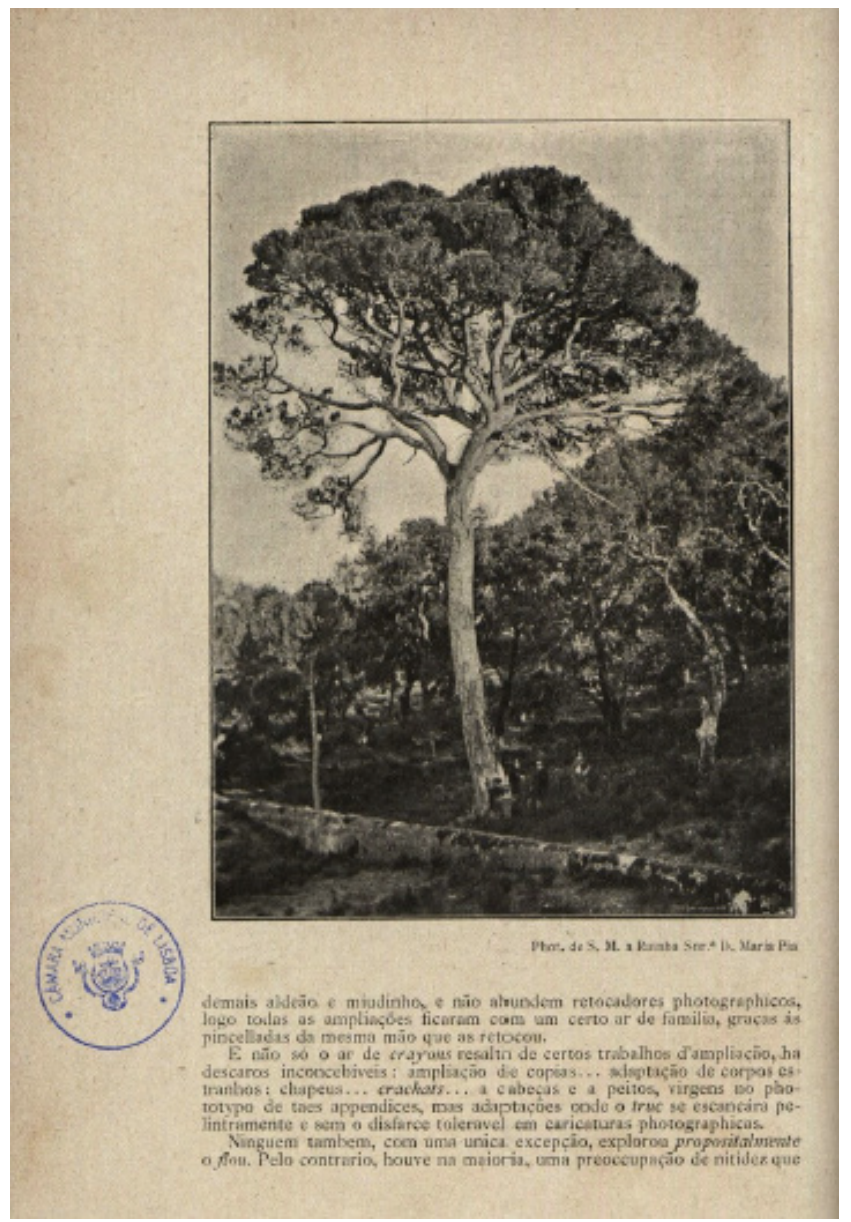

Figure 10: Boletim Photographico with a photograph by Maria Pia, exhibited in the I National Exhibition of Amateur Pho-tographers

Source: A exposição nacional de photographia, 1900, p. 28; Hemeroteca Municipal de Lisboa

There were "about 100 exhibitors applying to the exhibition" (Exposição nacional de photographia, 1900, p. 1), but "the exhibitors [approved] were (...) in number 52" (A exposição nacional de photographia, 1900, p. 26). Among which, in addition to Maria Pia, there is only another woman, D. Luiza Thomar, which received an honorable mention: "Lady Luiza Thomar exhibited photo miniatures and it was the only competitor that has approached this genre. Her photo miniatures, which were reproductions of paintings, are of a fancy coloured" (A exposição nacional de photographia, 1900, p. 26).

In any case, if the recognition of the work of Maria Pia seems to be genuine, the award of a gold medal, out-of-competition, seems to fit into the protocol obligations towards royal members ${ }^{13}$. The possibility of being regarded as a true artist is always guided by her status as a queen and a woman. Towards women photographers, there were abundant expressions of surprise (even if they were pleasant surprises). These expressions made evident the latent perceived conflict with the norm establishing a symbolic equivalent between being an artist and the male gender.

\footnotetext{
${ }_{13}$ "We highlight, out of the contest, the exhibition of photographies of Your Royal Highness the King D. Carlos, Your Royal
} Highness Lady Maria Pia and Your Royal Highness Infant D. Affonso" (A exposição nacional de photographia, 1900, p. 19). 


\section{FinAL REMARKS}

Since her own time, Maria Pia was seen as "someone who knows how to present herself as a queen", someone who is naturalized as an object of the gaze, as an image herself. She was frequently described as making a huge public impact with "her elegant figure" at all public occasions on which she standed (Vicent, 1988). This positioning tended to be repeated and perhaps expanded in the historiography in general and also in the historiography of photography. An interest spreading among private photography collectors. This "appetite" for collecting Maria Pia's images is justified by the increased circulation of images with the queen (when compared to the circulation of images produced by the queen), but also because this approach corresponds to the unquestionable expectations that linger on the visual.

In fact, in our histories it is this facet as a photographed object of the gaze, that has deserved more attention (Vicent, 1988; Andrade, 2011; Lopes, 2011). This does not happen by chance but because there is a cultural construction of the gaze that has gender. Let us remember "Blow up!", Antonioni's film, which illustrates expressively the definition of the photographer as being a man (and also, often, white) while those who were photographed were all (in the film, exclusively) women. As John Berger once wrote: "men act, women appear" (Berger, 1982, p. 51).

In monarchies the preponderance of the representation of the self is a rule, in the framework of the "representative public sphere" (Habermas,1988), both for kings and for queens, princes and princesses. Novidades announced the opening of the 1899 exhibition in the following terms: "Lady Maria Pia dressed a very rich toilet, in purple velvet with trimmings of fur. The infant wore his uniform of lieutenant colonel of artillery" (A Exposição Nacional de Photographias, 1899, s.p.). The reporter's attention did not forget to mention the public: "the galleries were crowded with ladies, that rose up, standing to the arrival of the royal family. At this moment, the look of the room was truly beautiful". Who were these ladies? Would they be there only to see the kings and queens or were they truly interested in the photographic art? We are left to wonder.

The diversity of ways in which the queen Maria Pia was represented, and the multiplicity of authors and photographic studios she elected, make these images a theme of greater importance for the history of photography in Portugal. However, the same could be said of her artistic activities. These have been mentioned, but little shown and discussed. The absence of this other facet of Maria Pia as a producer of images, reveals still the difficulties of our historiography in confronting its own models of past construction and its difficulties in asking questions about the invisibility processes going on. Often this is the case when we deal with the activities of women. And as we can see, even when they are queens.

Translated by Teresa Mendes Flores 


\section{BIBLIOGRAPHIC REFERENCES}

AA.VV. (2015). Tirée par...A rainha D. Amélia e a fotografia. Catálogo da exposição. Lisbon: Documenta.

AA.VV. (2016) Um Olhar Real. Obra artística da rainha D. Maria Pia - desenho, aguarela e fotografia. Lisbon: Palácio Nacional da Ajuda e Imprensa Nacional Casa da Moeda.

A exposição nacional de photographia (1900, February). Boletim Photographico, 2, pp. 17-29.

A Exposição Nacional de Photographias (1899, $31^{\text {st }}$ December). Novidades.

A mulher e a fotografia (1909, February). Echo Photographico, 36, pp. 18-19.

A rainha de Inglaterra, amadora de photographia (1905, April), Boletim Photographico, 64, p. 50.

Andrade, M. do C. R. de (2011). Maria Pia de Sabóia. Fotobiografia. Lisbon: INCM and Instituto dos Museus e da Conservação/Palácio da Ajuda.

Barnes, C. W. (1889, December) Why Ladies Should be Admitted to Membership in Photographic Societies. The American Amateur Photographer, 1(6), 223-224.

Barros, J. L. (2009). Amélia Rey Colaço: Fotobiografia. Lisbon: Círculo de Leitores.

Baudelaire, C. (1987). Lettre a M. le Directeur de la Revue Française sur le Salon de 1859. In Du Bon Usage de la Photographie: Une anthologie de textes (pp. 27-35). Paris: Centre National de la Photographie.

Berger, J. (1982). Modos de Ver. Lisbon: Edições 70.

Collin, F. (2010). O feminino na filosofia pós-metafísica. In T. Joaquim (Ed.), Masculinidades/Feminilidades (pp. 17-25). Porto: Edições Afrontamento,

Denny, M. (2009). Royals, Royalties and Remuneration: American and British Women Photographers in the Victorian Era. Women's History Review, Vol. 18, No ${ }_{5}$, 801-818.

Denny, M, (2012). Catherine Weed Barnes Ward: Advocate for Victorian Women Photographers. History of Photography. 36(2), 156-171. doi: 10.1080/03087298.2012.654938

Echo Photographico, Jornal Mensal de Sport Photographico (1907, June). Echo Phographico, 13, cover.

Editorial (1909, January). Echo Photographico, 35, p. 2.

Eu sou o tareco! (1907, March). Echo Photographico, 10, p. 76.

Exposição nacional de photographia (1900, $14^{\text {th }}$ January). O Século, p. 1.

Fonseca, C. S. (2016). Uma família de fotógrafos. Carlos e Margarida Relvas. Lisbon: Chiado Editores.

Galeria de Amadores Contemporâneos: D. Maria C. Godinho (1907, August). Echo Photographico, 15, p. 17.

Galeria de Amadores Contemporâneos: Nathalia Terra (1908, May). Echo Photographico, 24, p. 89.

Habermas, J. (1988). L'espace publique. Archéologie de la publicité comme dimension constitutive de la bourgeoisie. Paris: Payot.

Hunt, J. D. (2002). The Picturesque Garden in Europe. London: Thames\&Hudson. 
Jardim, M. do R. (2016). Fotografias de S.M. a Rainha D. Maria Pia. In Um Olhar Real. Obra artística da Rainha D. Maria Pia. Catálogo da exposição homónima. (pp. 167-181). Lisbon: INCM and Palácio da Ajuda.

Leandro, S. (2011). Boa figura, má figura, sem figura: Mulheres artistas no tempo da $1^{\text {a }}$ República. In Z. O. Castro, J. Esteves \& N. Monteiro (Org.), Mulheres na Primeira República. Percursos, conquistas e derrotas (pp. 271-318). Lisbon: Edições Colobri.

Lopes, M. A. (2011). Rainhas que o povo amou. Estefânia de Hohenzollern. Maria Pia de Saboia. Lisbon: Círculo de Leitores.

Martins, C. (2005). Arendt: a perspectiva feminina do espaço público?. In Liuro de Atas do $4^{\circ}$ Congresso da SOPCOM (pp. 701-711). Covilhã: Labcom.

McLaughlin, L. (2004). Para além das 'esferas separadas': o feminismo e o debate dos estudos culturais/ economia política. In M. J. Silveirinha (Ed.), As Mulheres e os Media (pp. 97-122). Lisbon: Livros Horizonte.

Mendes Flores, T. (2016) A paisagem pitoresca e o daguerreótipo no pensamento geográfico de Alexander Von Humboldt. Ponto de Acesso, 10(3), 4-20.

Mitchell, W.C.T. (1995). Interdisciplinarity and Visual Culture. Art Bulletin, LXXVII(4), 540-544.

Mulvey, L. (1989). Visual and Other Pleasures. Bloomington and Indianapolis: Indiana University Press.

Nameghy, K. M. \& Gonzaléz, C. P. (2013). From Sitters to Photographers: Women in Photography from the Qajar Era to the 1930's. History of Photography. 37(1), 48-73.

Nochlin, L. (1988). Women, Art and Power, and Other Essays. New York: Harper\&Row.

Pallier, J. (2006). Maria Pia: a mulher que queria ser rainha. Lisbon: Bertrand Editores.

Pavão, J. M. \& Cerqueira, J. (2007). Maria Pia: Rainha e mulher. Mirandela: João Azevedo Editor.

Photographers at Work, Young Women Becoming Enthusiastic Over the Art (1890, $2^{\text {nd }} J$ une). New York Times, p. 8.

Pollock, G. (1987). Vision and Difference. Feminism, Feminity and Histories of Art. Massachussets: Methuen Publishing.

Rosenblum, N. (1994). History of Women Photographers. New York: Abbeville Press.

Sena, A. (1998). História da imagem fotográfica em Portugal-1839-1997. Porto: Porto Editora.

Silva, J. P. N. da (1865), Descrição artística das novas salas do Real Paço d'Ajuda (Obras mandadas executar por Sua Magestade a Senhora D. Maria Pia de Saboia nos seus Reais Aposentos). Lisbon: Thypographia Portuguesa.

Silva, R. H. da \& Monge, M. de J. (2007). 1863-1908, El-Rei Dom Carlos, pintor. Caxias: Fundação Casa de Bragança.

Smith, L. (2015). A Royal Passion: Queen Victoria and Photography. History of Photography, 39(2), $196-198$. doi: $10.1080 / 03087298.2015 .1030182$.

Tavares, E. \& Medeiros, M. (2015). Tesouros da fotografia portuguesa do século XIX. Lisbon: Edições do MNAC.

Tavares, M. (2011). Feminismos: percursos e desafios (1947-2007). Lisbon: Texto Editores. 
Vaz, J. (2016). D. Maria Pia de Saboia. Um olhar real. In Um Olhar Real. Obra artística da Rainha D. Maria Pia. Catálogo da exposição homónima (pp. 11-146). Lisbon: INCM e Palácio da Ajuda.

Vicente, A. P. (1988). D. Maria Pia e os seus fotógrafos. S.I.: s.n...National Library Code: $\mathrm{n}^{\circ} 18776$.

Vicente, F. L. (2012). A arte sem história. Mulheres e cultura artística (séculos XVI-XX). Lisbon: Athena.

Vicente, F. L. (Ed.) (2016). Aurélia de Sousa. Mulher artista (1866-1922). Lisbon: Tinta da China.

Wells, L. (2003). The Photography Reader. London: Routledge.

Women Who Press the Button (1893, $1^{\text {st }}$ October). New York Times, p. 18.

Woolf, V. (1931). A Room of One's Own. London: Hogarth Press.

\section{FinAnCial Support:}

Post-Doctoral Fellowship by Fondation for Science and Technology (SFRH/ $\mathrm{BPD} / 72321 / 2010)$.

\section{Biographical Note}

Teresa Mendes Flores holds a Phd. in Communication Sciences by Universidade Nova de Lisboa (2010). She is Assistant Professor at ECATI, Universidade Lusófona since 1997 and is an integrated researcher at CIC.Digital-FCSH. She contributes in the fields of photography and film studies, Visual Culture and Gender Studies. She is a postdoctoral fellow conducting a research about the photographies produced during the $19^{\text {th }}$ century Portuguese Scientific Expeditions to Africa. She published the book Cinema e Experiência Moderna (MinervaCoimbra, 2007) and co-edited Photography and Cinema. Fifty Years of Chris Marker's La Jetée (British Schollars 2015). She is part of the editorial team of the book collection Media e Jornalismo and the journal Revista de Comunicação $e$ Linguagens. She is currently vice-president of CECL and a member of the Direction Board of the Iberian Association of Semiotics.

E-mail: teresa.flores@sapo.pt

Universidade Lusófona de Humanidades e Tecnologias, Avenida do Campo Grande, 376, 1749-024 Lisbon, Portugal

* Submmitted: 15-08-2017

* Accepted: 30-09-2017 